\title{
In vitro Bio-Efficacy of Fungicides and Bioagents against Dry Root Rot of Safflower
}

\author{
V. M. Gholve ${ }^{1 *}$, P.N. Gawande ${ }^{2}$ and S.B. Ghuge ${ }^{2}$ \\ ${ }^{1}$ Plant Pathology, Sorghum Research Station, ${ }^{2}$ Safflower Research Station, V.N. Marathwada \\ Krishi Vidyapeeth, Parbhani-431 402, Maharashtra, India \\ *Corresponding author
}

A B S T R A C T

\begin{abstract}
Keywords
Dry root rot,

Safflower,

Fungicides,

Bioagents,

Management,

Macrophomina

phaseolina

Article Info

Accepted:

28 July 2020

Available Online:

10 August 2020

Among the diseases of safflower; dry root rot disease caused by Macrophomina phaseolina (Tassi.) Goid is one of the most destructive and wide spread diseases of Safflower (Carthamous tinctorius L.) causing accountable losses of about 25-60 per cent. A total of ten fungicides namely: Captan, Iprodine, Copper Oxychloride, Thiram Mancozeb, Difenconazole, Propiconazole, Cymoxanil8\%+Mancozeb 64\%, Carbandazim, \& Metalaxyl 8\% + Mancozeb 64\% were evaluated in vitro against Macrophomina phaseolina.All the fungicides (10) tested caused significant inhibition at all the concentration over contol. However fungicides viz., Carbendazim, Metalaxyl + Mancozeb and Mancozeb (recorded significantly highest average mycelial growth inhibition of 100.00, 91.42 and 85.86 per cent, respectively. Bioagents (6) evaluated in vitro were found fungistatic/antifungal against M. phaseolina. However, Fungal antagonists $T$. viride, $T$. harzianum and $T$. hamatum recorded significantly highest mean mycelial inhibition, respectively of $80.00,77.07$ and 66.22 per cent.
\end{abstract}

\section{Introduction}

Safflower (Carthamous tinctorius L.) commonly known as Kardi (Marathi), Kusube (Kannada), Kusum (Hindi) and Kusumba (Telugu) is one of the important Rabi oilseed crop of the country originated from Abyssinia and Afghanistan. It is drought tolerant, selfpollinated crop belonging to the family compositae or asteraceae. The world area under safflower is 8.22 lakh ha with 5.83 lakh tones production and productivity of 709 $\mathrm{kg} / \mathrm{ha}$. India is in first place in terms of area and production of safflower in the world. In India safflower is raised over an area of 296.0lakh ha with a production of 180.0 lakh tones. The important states growing safflower are Maharashtra, Karnataka, Andhra Pradesh, Madhya Pradesh, Gujarat, Orissa and Bihar. In Maharashtra it has occupied an area of 193 lakh ha with a production of 114 lakh tones and productivity of $510 \mathrm{~kg} / \mathrm{ha}$ (Anonymous 2013-2014).

Among the diseases of safflower; dry root rot disease caused by Macrophomina phaseolina 
(Tassi.) Goid is one of the most destructive and wide spread diseases of Safflower (Carthamous tinctorius L.) causing accountable losses of about 25-60 per cent. It is the major soil borne disease and appears sporadically all over the country (Shambharkar and Indi, 1987). Occurrence of this disease on safflower in India was first reported by Amarsingh and Bhowmik (1979) from IARI, New Delhi and later on by others from different parts of the country (Kore and Deshmukh, (1982) and Lukade, (1992) from Maharashtra; Singh et al., (1987) from M.P).

The pathogen Macrophomina phaseolina has been reported to infect safflower at various growth stages of the plant. Affected plants showed grayish black discoloration at collar region from where the plant later broke. The lateral roots were turned black and their skin was easily sloughed off exposing the inner cortical tissues. Affected portion was covered with small, numerous, black sclerotia. These symptoms were more prominent after flowering and their severity increased at maturity. Above ground appearance of disease plant was expressed with yellow, dried leaves, finally wilting the plant completely which could easily be pulled out from soil (Amarsingh and Bhowmik, 1979).It has therefore become highly essential to have a good knowledge of such association, method of detection as well as way to control them. Considering economic importance of the disease, the present investigation was undertaken.

\section{Materials and Methods}

\section{In vitro efficacy of fungicides}

Efficacy of 10 fungicides viz Captan, Iprodine, Copper Oxychloride, Thiram Mancozeb, Difenconazole, Propiconazole, Cymoxanil $8 \%+$ Mancozeb 64\%, Carbandazim, \& Metalaxyl 8\% + Mancozeb 64\% was evaluated systemic (@ 500, 1000 and 1500 ppm conc) and non- systemic (@1000, 1500 and 2000 ppm conc) in vitro against M. phaseolina, by Poisoned food technique (Nene and Thapliyal, 1993), using PDA as basal culture medium. Based on active ingredient, the requisite quantity of each test fungicide was calculated and mixed thoroughly with autoclaved and cooled $\left(40^{\circ} \mathrm{C}\right)$ Potato Dextrose Agar medium (PDA) separately in conical flasks to obtain desired concentrations of 500,1000, 1500 and 2000 ppm. Fungicide amended PDA medium was then poured $(20 \mathrm{ml} /$ plate $)$ aseptically in Petri plates $(90 \mathrm{~mm}$ dia.) and allowed to solidify at room temperature. For each test fungicide and its test concentration, three replications were maintained. After solidification of the medium, all the plates were inoculated aseptically with a $5 \mathrm{~mm}$ culture disc obtained from a week old actively growing pure culture of M. phaseolina. The culture disc was placed on PDA in inverted position in the centre of the Petri plate and plates were incubated at $28 \pm 2^{0} \mathrm{C}$. Petri plates filled with plain PDA (without any fungicide) and inoculated with the culture disc of the test pathogen were maintained as control (untreated).

Observations on radial mycelial growth/colony diameter of the pathogen were recorded at 24 hrs. interval and continued till the untreated control plate was fully covered with mycelial growth of the test pathogen. Per cent mycelial growth inhibition of the test pathogen with the test fungicides over untreated control was calculated by applying the following formula (Vincent, 1927).

Per cent Inhibition $(I)=\frac{C-T}{C} \times 100$ Where, $\mathrm{C}=$ Growth $(\mathrm{mm})$ of test fungus in untreated control plate

$\mathrm{T}=$ Growth $(\mathrm{mm})$ of test fungus in treated plates 


\section{In vitro efficacy of bioagents}

Five fungal antagonists viz., Trichoderma viri de, T. harzianum, T. koningii, T. hamatum, T. virens and one bacterial antagonists viz., Pseudomonas fluorescens were evaluated in vitro against $M$. phaseolina, applying Dual culture technique (Dennis and Webster, 1971). Seven days old cultures of the test bioagents and the test pathogen ( $M$. phaseolina) grown on agar media were used for the study. The culture disc $(5 \mathrm{~mm})$ of the test pathogen and bioagent were cut out with sterilized cork borer, from a week old culture. Then two culture discs, one each of the test pathogen and bioagent were placed aseptically at equidistance and exactly opposite with each other on solidified PDA medium in Petri plates and plates were incubated at $28 \pm 2^{0} \mathrm{C}$. Three replications were maintained. PDA plates inoculated only with culture disc of the test pathogen were maintained as untreated control.

Observations on linear mycelial growth of the test pathogen and bioagent were recorded at an interval of 24 hours and continued till untreated control plate was fully covered with mycelial growth of the test pathogen. Per cent inhibition of the test pathogen over untreated control was calculated by applying the following formula (Arora and Upddhyay, 1978).

Percent growth Inhibition $=$

Colony growth in - Colony growth in Control plate intersecting plate

Colony growth in control plate

\section{Results and Discussion}

\section{In vitro evaluation of fungicides}

A total of 10 fungicides (systemic @ 500, 1000 and 1500 ppm conc. and non systemic
@ 1000, 15000 and 2000 ppm conc.) evaluated in vitro against $M$. phaseolina exhibited a wide range of mycelial growth and inhibition of the test pathogen. The results obtained are presented in the Table 1 Figure 1, 2, 3, 4 and PLATE-I.

\section{Mycelial growth}

At $500 \mathrm{ppm}$, systemic fungicide (Table1,fig. 1 and PLATE-I) radial mycelial growth of the test pathogen was ranged from $00.00 \mathrm{~mm}$ (Carbendazim) to $40.00 \mathrm{~mm}$ (Cymoxanil + Mancozeb), as against $90.00 \mathrm{~mm}$ in untreated control. However, Carbendazim was found with none of the mycelial growth. This was followed by the fungicides viz., Metalaxyl + Mancozeb (11.00mm), Propiconazole (18.33mm), Difenconazole (25.66mm). Fungicide Cymoxanil + Mancozeb were found less effective with maximum mycelial growth of $40.00 \mathrm{~mm}$.

At $1000 \mathrm{ppm}$, systemic and non systemic (Table 1,fig. 2 and PLATE-I) all the 10 fungicides tested exhibited similar trend of radial mycelial growth as that of observed at $500 \mathrm{ppm}$, but it was comparatively reduced and was ranged from $00.00 \mathrm{~mm}$ (Carbendazim) to $37.50 \mathrm{~mm}$ (Copper oxychloride), as against $90.00 \mathrm{~mm}$ in untreated control. However, none of the mycelial growth was recorded with Carbendazim $(00.00 \mathrm{~mm})$. This was followed by the fungicides viz., Metalaxyl + Mancozeb $(8.00 \mathrm{~mm}), \quad$ Propiconazole $(15.00 \mathrm{~mm})$, Mancozeb (16.00 mm), Difenconazole $(20.33 \mathrm{~mm})$, Thiram $(20.66 \mathrm{~mm})$, Captan $(28.33 \mathrm{~mm})$, Iprodine $(35.00 \mathrm{~mm})$ and Cymoxanil + Mancozeb (36.66 $\mathrm{mm})$ as against $90.00 \mathrm{~mm}$ in untreated control. Copper oxychloride was found comparatively less effective with maximum mycelial growth of $37.50 \mathrm{~mm}$. At $1500 \mathrm{ppm}$, systemic and non systemic (Table 1,fig. 3 and PLATE-I) all the 10 fungicides tested exhibited similar trend of mycelial growth as that of observed at 500 
ppm and $1000 \mathrm{ppm}$ and it was ranged from $00.00 \mathrm{~mm}$ (Carbendazim) to $33.00 \mathrm{~mm}$ (Copper oxychloride), as against $90.00 \mathrm{~mm}$ untreated control. However, with the fungicide Carbendazim growth was observed. This was followed by the fungicides Metalaxyl + Mancozeb (4.16mm), Propiconazole $\quad(11.66 \mathrm{~mm}), \quad$ Mancozeb (13.50mm), Difenconazole (17.33mm), Thiram (17.66mm), Captan (22.33mm), Iprodine (31.00mm), Cymoxanil + Mancozeb (33.00). Copper oxychloride was found comparatively less effective with maximum mycelial growth of $34.00 \mathrm{~mm}$.

At 2000 ppm, non systemic fungicide (Table 1, figure 4 and PLATE I) radial mycelial growth of the test pathogen was ranged from $8.66 \mathrm{~mm}$ (Mancozeb) to $31.33 \mathrm{~mm}$ (Copper oxychloride), as against $90.00 \mathrm{~mm}$ in untreated control. However, Mancozeb was found with $8.66 \mathrm{~mm}$ of the mycelial growth. This was followed by the fungicides viz., Thiram $(14.00 \mathrm{~mm})$, Captan $(19.66 \mathrm{~mm})$ and Iprodine $(28.00 \mathrm{~mm})$. Fungicides Copper oxychloride was found comparatively less effective with maximum mycelial growth of $31.33 \mathrm{~mm}$.

\section{Mycelial growth inhibition}

Results (Table 1, fig. 1 and PLATE-I) revealed that all the 10 fungicides tested (@ 500, 1000, 1500 and 2000 each) significantly inhibited mycelial growth of $M$. phaseolina, over untreated control $(00.00 \%)$. Further, the percentage mycelial growth inhibition was increased with increase in concentrations of the fungicides tested

At 500 ppm, systemic fungicide (Table 1,fig. 1 and PLATE-I) mycelial growth inhibition of the test pathogen was ranged from 55.55 (Cymoxanil + Mancozeb) to 100.00 per cent (Carbendazim). However, fungicide Carbendazim was found best inhibited cent per cent $(100.00 \%)$ mycelial growth. The second and third best fungicides found were Metalaxyl + Mancozeb (87.77\%) and Propiconazole $(79.62 \%)$ was followed by Difenconazole $(71.85 \%)$ Cymoxanil was found least effective $(55.55 \%)$.

At 1000 ppm, systemic and non systemic (Table 1,fig. 2 and PLATE-I) mycelial growth inhibition was increased compared to 500 ppm and it was ranged from 58.32 (Copper oxychloride) to 100.00 (Carbendazim) per cent. However, fungicide Carbendazim caused cent per cent $(100.00 \%)$ mycelial inhibition was followed by the fungicides, viz., Metalaxyl + Mancozeb (91.11\%) and Propiconazole (83.33), and Mancozeb $(82.22 \%)$.This was followed by Thiram (77.03\%), Difenconazole (77.40\%), Captan (68.51\%), Iprodine (61.11\%), Cymoxanil + Mancozeb (59.62\%). Copper oxychloride was found least effective $(58.32 \%)$.

At 1500 ppm, systemic and non systemic (Table 1, figure 3 and PLATE-I) mycelial growth inhibition was increased compared to $500 \mathrm{ppm}, 1000 \mathrm{ppm}$ and it was ranged from 62.22 (Copper oxychloride) to 100.00 (Carbendazim) per cent. However, fungicide Carbendazim caused cent per cent $(100.00 \%)$ mycelial inhibition was followed by the fungicides, viz., Metalaxyl + Mancozeb (95.39\%), Propiconazole (87.58), Mancozeb $(85.00 \%)$, Difenconazole $(80.74 \%)$, Thiram $(80.37 \%)$. This was followed by Captan (75.18\%), Iprodine (65.55\%), Cymoxanil + Mancozeb (63.33\%). Copper oxychloride was found least effective (62.22\%).

At 2000 ppm, non systemic (Table 1, figure 4 and PLATE-I) fungicides tested exhibited comparatively increased mycelial growth inhibition than that of at 500, 1000 and $1500 \mathrm{ppm}$ and it was ranged from 65.18 (Copper oxychloride) to 90.37 (Mancozeb) per cent inhibition of mycelial growth of the 
test pathogen. However, fungicide Mancozeb caused cent per cent (90.37\%) mycelial inhibition was followed by the fungicides, viz., Thiram (84.44\%), Captan (78.14\%), Iprodine $(68.88 \%)$, and Copper oxychloride $(65.18 \%)$. Thus, all the fungicides tested were found fungistatic against $M$. phaseolina and significantly inhibited its mycelial growth over untreated control. However, fungicides found most effective in the order of merit were Carbendazim, Metalaxyl + Mancozeb, Mancozeb, Propiconazole, Thiram, Difenconazole, Captan, Cymoxanil, Iprodine and Copper oxychloride.

Table.1 In vitro efficacy of fungicides against mycelial growth and inhibition of M. phaseolina

\begin{tabular}{|c|c|c|c|c|c|c|c|}
\hline \multirow{2}{*}{$\begin{array}{l}\text { Tr. } \\
\text { No. }\end{array}$} & \multirow[b]{2}{*}{ Treatments } & \multicolumn{3}{|c|}{ Col. dia. $*(\mathrm{~mm})$ at Conc. } & \multicolumn{3}{|c|}{$\%$ Inhibition* } \\
\hline & & $\begin{array}{l}1000 \\
\text { ppm }\end{array}$ & $\begin{array}{l}1500 \\
\text { ppm }\end{array}$ & $\begin{array}{l}2000 \\
\text { ppm }\end{array}$ & $\begin{array}{l}1000 \\
\text { ppm }\end{array}$ & $\begin{array}{l}1500 \\
\text { ppm }\end{array}$ & $\begin{array}{l}2000 \\
\text { ppm }\end{array}$ \\
\hline \multicolumn{8}{|c|}{ Non-systemic fungicides } \\
\hline $\mathrm{T}_{1}$ & Captan 50WP & 28.33 & 22.33 & 19.66 & $\begin{array}{c}68.51 \\
(43.23)\end{array}$ & $\begin{array}{c}75.18 \\
(48.74)\end{array}$ & $\begin{array}{c}78.14 \\
(51.38)\end{array}$ \\
\hline $\mathrm{T}_{2}$ & Iprodine & 35.00 & 31.00 & 28.00 & $\begin{array}{c}61.11 \\
(37.66)\end{array}$ & $\begin{array}{c}65.55 \\
(40.96)\end{array}$ & $\begin{array}{c}68.88 \\
(43.53)\end{array}$ \\
\hline $\mathrm{T}_{3}$ & $\begin{array}{l}\text { Copper oxychloride } \\
\text { 50WP }\end{array}$ & 37.50 & 34.00 & 31.33 & $\begin{array}{c}58.32 \\
(35.67)\end{array}$ & $\begin{array}{c}62.22 \\
(38.47)\end{array}$ & $\begin{array}{c}65.18 \\
(40.67)\end{array}$ \\
\hline $\mathrm{T}_{4}$ & Thiram 75 WP & 20.66 & 17.66 & 14.00 & $\begin{array}{c}77.03 \\
(50.38)\end{array}$ & $\begin{array}{c}80.37 \\
(53.48)\end{array}$ & $\begin{array}{c}84.44 \\
(57.61)\end{array}$ \\
\hline $\mathrm{T}_{5}$ & Mancozeb 75WP & 16.00 & 13.50 & 8.66 & $\begin{array}{c}82.22 \\
(55.29)\end{array}$ & $\begin{array}{c}85.00 \\
(58.23)\end{array}$ & $\begin{array}{c}90.37 \\
(64.65)\end{array}$ \\
\hline $\begin{array}{l}\text { Tr. } \\
\text { No. }\end{array}$ & Treatments & $\begin{array}{c}500 \\
\text { ppm }\end{array}$ & $\begin{array}{l}1000 \\
\text { ppm }\end{array}$ & $\begin{array}{l}1500 \\
\text { ppm }\end{array}$ & 500 ppm & $\begin{array}{l}1000 \\
\text { ppm }\end{array}$ & $\begin{array}{l}1500 \\
\text { ppm }\end{array}$ \\
\hline \multicolumn{8}{|c|}{ Systemic / Combi fungicides } \\
\hline $\mathrm{T}_{6}$ & Difenconazole & 25.66 & 20.33 & 17.33 & $\begin{array}{c}71.85 \\
(45.93)\end{array}$ & $\begin{array}{c}77.40 \\
(50.74)\end{array}$ & $\begin{array}{c}80.74 \\
(53.83)\end{array}$ \\
\hline $\mathrm{T}_{7}$ & Propiconazole & 18.33 & 15.00 & 11.16 & $\begin{array}{c}79.62 \\
(52.77)\end{array}$ & $\begin{array}{c}83.33 \\
(56.44)\end{array}$ & $\begin{array}{c}87.58 \\
(61.16)\end{array}$ \\
\hline $\mathrm{T}_{8}$ & $\begin{array}{l}\text { Cymoxanil 8\%+ } \\
\text { Mancozeb 64\% (72WP) }\end{array}$ & 40.00 & 36.33 & 33.00 & $\begin{array}{c}55.55 \\
(33.74)\end{array}$ & $\begin{array}{c}59.62 \\
(36.59)\end{array}$ & $\begin{array}{c}63.33 \\
(38.47)\end{array}$ \\
\hline $\mathrm{T}_{9}$ & Carbendazim 50WP & 00.00 & 00.00 & 00.00 & $\begin{array}{l}100.00 \\
(89.98)\end{array}$ & $\begin{array}{l}100.00 \\
(89.98)\end{array}$ & $\begin{array}{l}100.00 \\
(89.98)\end{array}$ \\
\hline $\mathrm{T}_{10}$ & $\begin{array}{l}\text { Metalyxl 8\% + } \\
\text { Mancozeb64\% (72WP) }\end{array}$ & 11.00 & 8.00 & 4.16 & $\begin{array}{c}87.77 \\
(61.42)\end{array}$ & $\begin{array}{c}91.11 \\
(65.64)\end{array}$ & $\begin{array}{c}95.39 \\
(72.48)\end{array}$ \\
\hline $\mathrm{T}_{11}$ & Control (Untreated) & 90.00 & 90.00 & 90.00 & $\begin{array}{c}00.00 \\
(00.00)\end{array}$ & $\begin{array}{c}00.00 \\
(00.00)\end{array}$ & $\begin{array}{c}00.00 \\
(00.00)\end{array}$ \\
\hline & S.E. \pm & 0.32 & 0.36 & 0.27 & 0.58 & 0.62 & 0.50 \\
\hline & C.D. $(P=0.05)$ & 0.96 & 1.06 & 0.79 & 1.70 & 1.82 & 1.47 \\
\hline
\end{tabular}

$*$-Mean of three replications, Col. $=$ Colony, Dia. $=$ Diameter, Conc. $=$ Concentration, $\quad$ Av. $=$ Average, Figures in parenthesis are arc sine transformed value 
Table.2 In vitro efficacy of bioagents against mycelial growth and inhibition of M. phaseolina

\begin{tabular}{|c|c|c|c|}
\hline Tr. No. & Treatments & Colony diameter* (mm) & $\%$ Inhibition \\
\hline $\mathrm{T}_{1}$ & Trichoderma viride & 18.00 & $\begin{array}{r}80.00 \\
(53.12)\end{array}$ \\
\hline $\mathrm{T}_{2}$ & Trichoderma harzianum & 20.66 & $\begin{array}{c}77.07 \\
(50.40)\end{array}$ \\
\hline $\mathrm{T}_{3}$ & Trichoderma koningii & 34.33 & $\begin{array}{c}61.85 \\
(38.20)\end{array}$ \\
\hline $\mathrm{T}_{4}$ & Trichoderma hamatum & 34.00 & $\begin{array}{c}66.22 \\
(38.47)\end{array}$ \\
\hline $\mathrm{T}_{5}$ & Trichoderma virens & 42.00 & $\begin{array}{c}53.33 \\
(32.23)\end{array}$ \\
\hline $\mathrm{T}_{6}$ & Pseudomonas fluorescens & 38.33 & $\begin{array}{c}57.04 \\
(35.03)\end{array}$ \\
\hline \multirow[t]{3}{*}{$\mathrm{T}_{7}$} & Control (untreated) & 90.00 & $\begin{array}{c}00.00 \\
(00.00)\end{array}$ \\
\hline & S.E. \pm & 0.56 & 0.78 \\
\hline & C.D. $(P=0.05)$ & 1.72 & 2.37 \\
\hline
\end{tabular}

*Mean of three replications, Figures in parenthesis are arc sine transformed values 


\section{PLATE I}
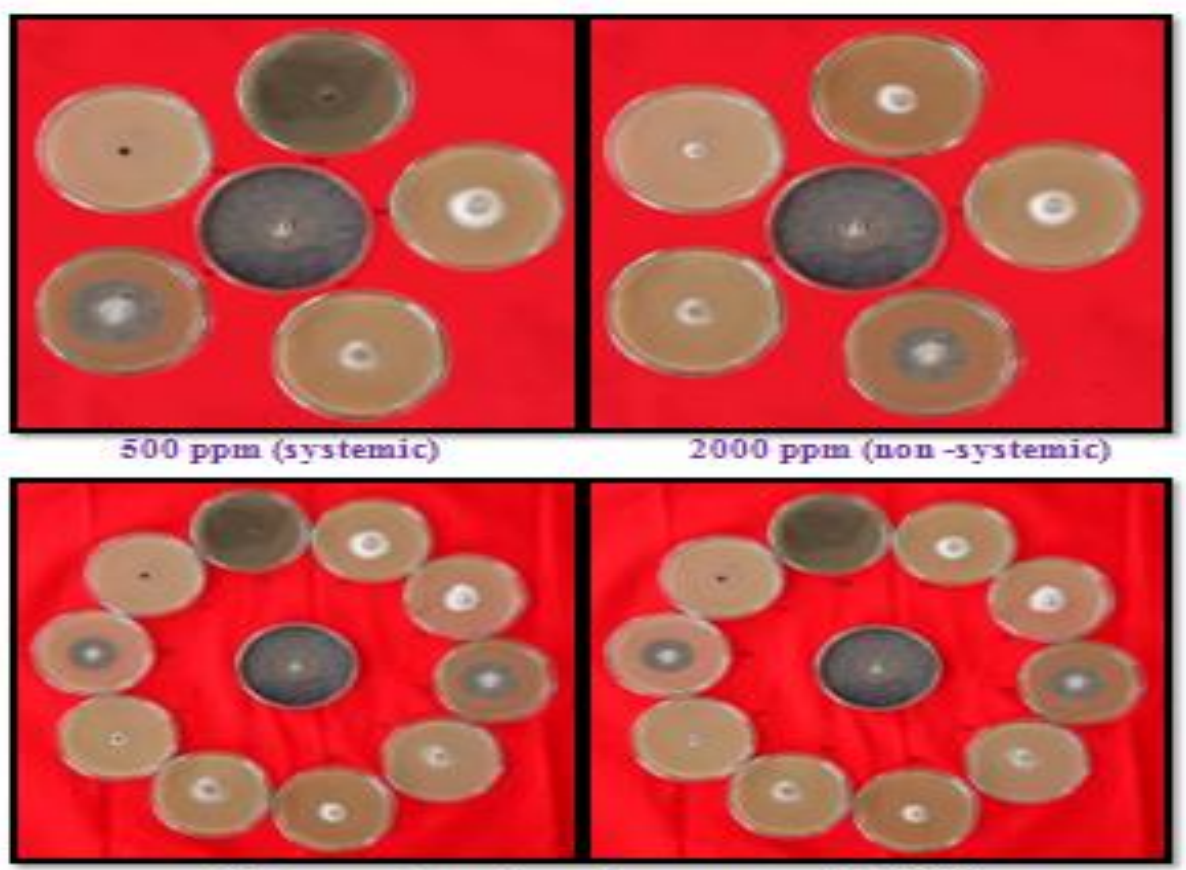

$1000 \mathrm{ppm}$ (systemic and non-systemic) $1500 \mathrm{ppm}$

$T_{1}$ : Captan $T_{7}:$ Propiconazole

$T_{2}$ : Iprodine

$T_{\mathrm{s}}$ : Cymoxamil + Mancozeb

$T_{1}$ : Copper oxychloride

$T_{*}:$ Thiram

$T_{s}:$ Carbendazim

$T_{s}$ Mancozrb

$T_{10}$ : Metalaxyis\% + Mancozeb $64 \%$

$T_{6}$ : Difenconazole

$T_{11}$ : Control (untreated)

In vitro effica oy of the systemic $(500,1000,1500 \mathrm{ppm})$ sud non systemic $(1000,1500$, $2000 \mathrm{ppm}$ ) fungicides agsinst mycelial growth andinhibition of $M$, phasealina 


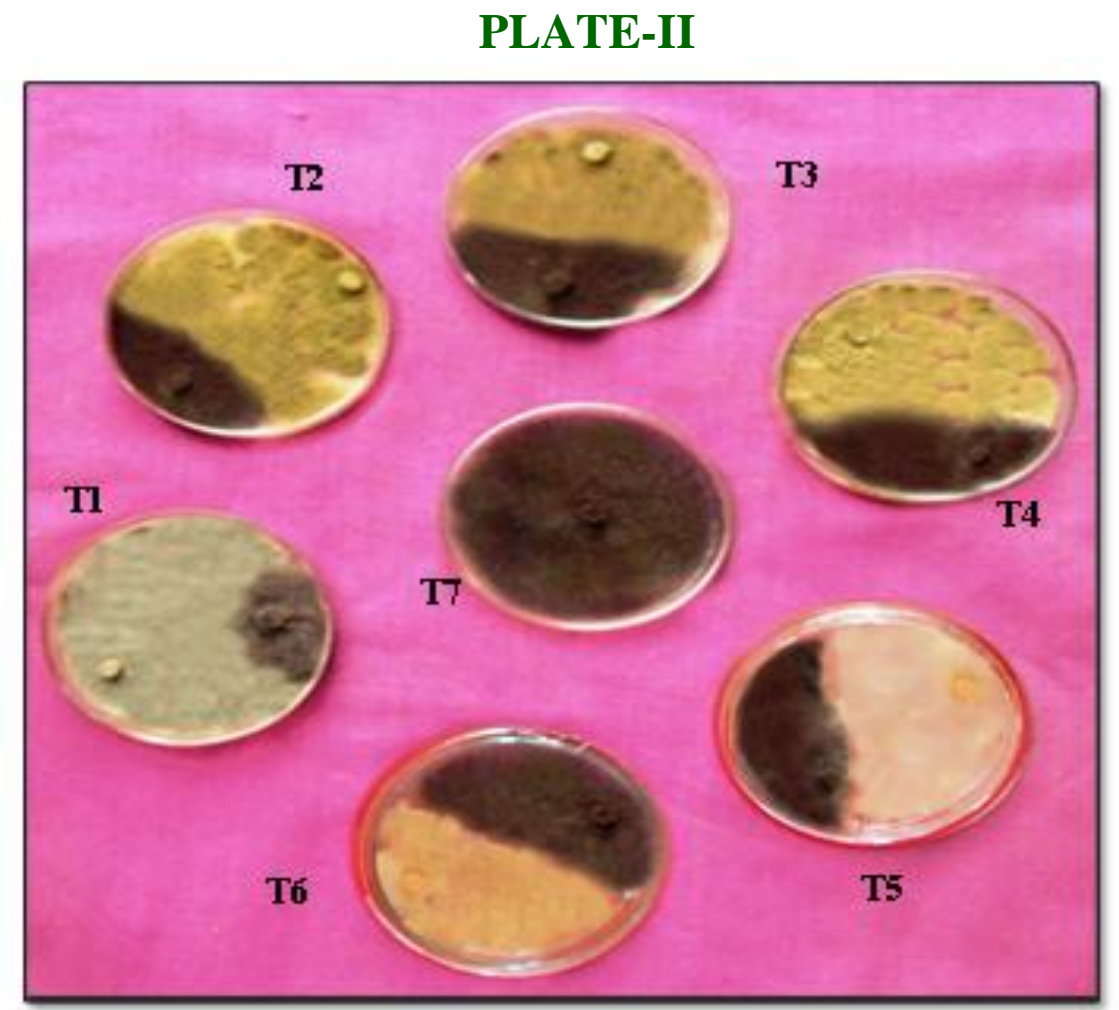
$\mathrm{T}_{1}$ : Trichoderma vitide
$\mathbf{T}_{5}:$ T.vitens
$\mathbf{T}_{2}:$ T. harzianum
$\mathbf{T}_{6}:$ Pseudomonas fluorescens
$\mathbf{T}_{3}:$ T. koningii
$\mathbf{T}_{7}$ : Control
$\mathbf{T}_{4}:$ T. hamatum
In vitro efficacy of the bioagents against mycelial growth and inhibition of M. phaseolina 


\section{Fig.1}

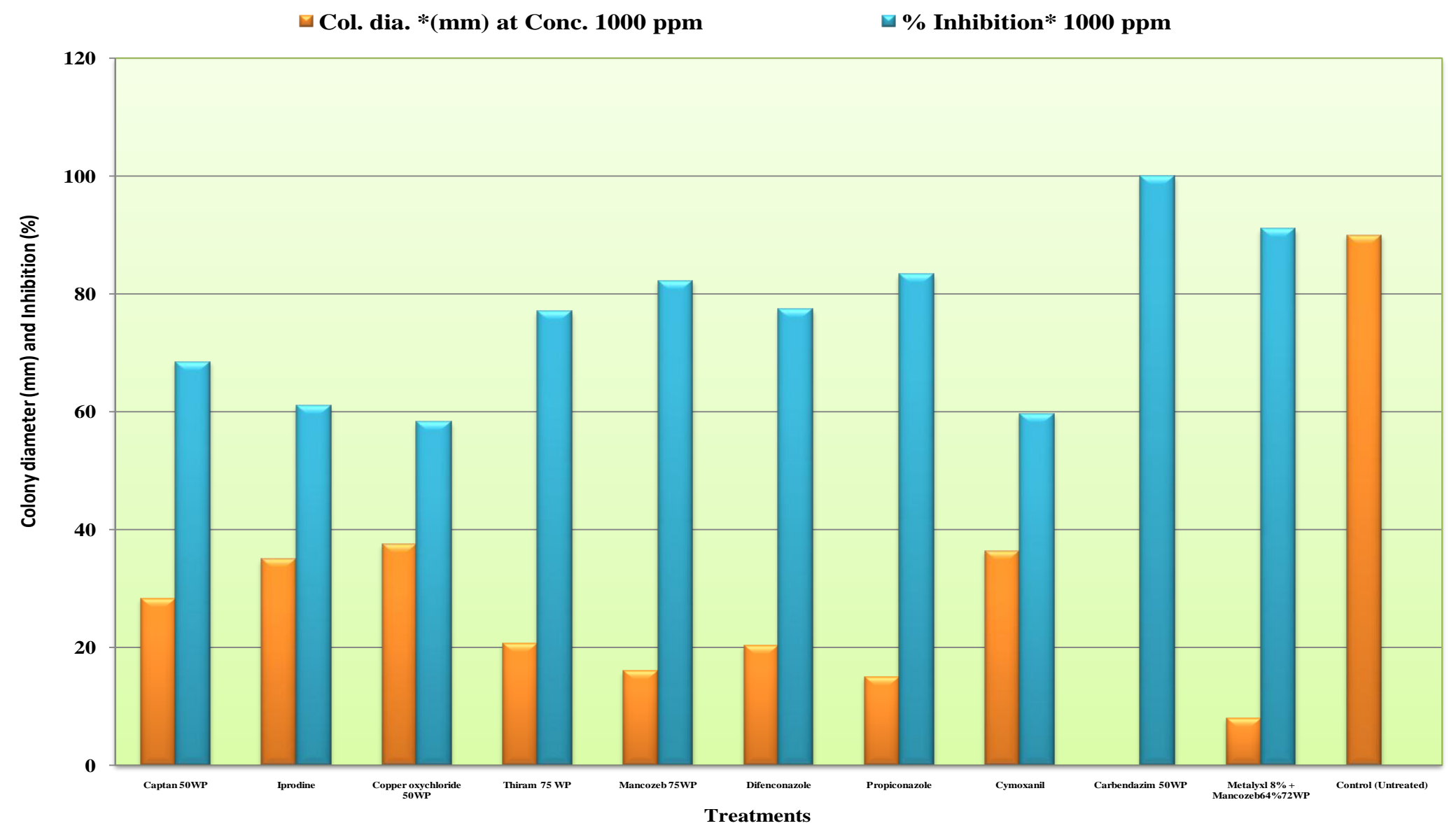

Fig 2. In vitro efficacy of systemic and non- systemic fungicides at $1000 \mathrm{ppm}$ against mycelial growth and inhibition of M. phaseolina 
Fig.2

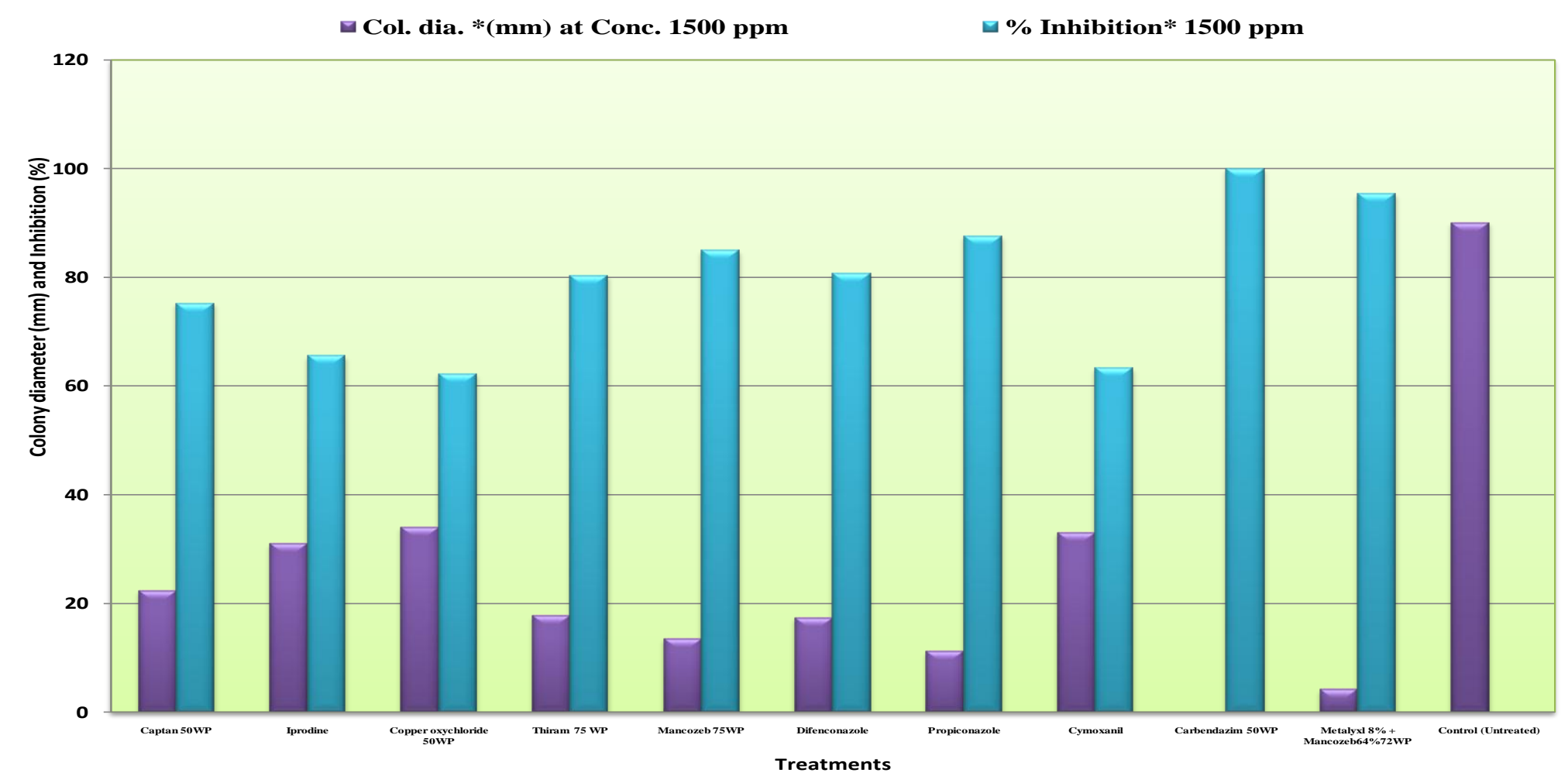

Fig 3. In vitro efficacy of systemic and non- systemic fungicides at 1500 ppm against mycelial growth and inhibition of M. phaseolina 
Similar fungistatic effects of the test fungicides against $M$. phaseolina infecting safflower and many other crops were reported earlier by several workers. Fungicides viz., Carbendazim, Metalaxyl + Mancozeb, Mancozeb, Propiconazole, Thiram, Difenconazole, Captan, Cymoxanil, Iprodine and Copper oxychloride.Were reported to cause significant mycelial growth inhibition of $M$. phaseolina, earlier by several workers (Srivastava and Tripathi, 1998; Lambhate et al., 2002; Malathi and Doraisamy, 2003; Meena et al., 2006; Prajapati et al., 2004; Verma and Ram, 2006; Suryawanshi et al., 2008; Tandel et al., 2010; Magar et al., 2011; Moradia, 2011; Kumari et al., 2012; Chaudhari and Chaudhari, 2012 and Arora et al., 2013).

\section{In vitro evaluation of bioagents}

The results obtained on mycelial growth and inhibition of $M$. phaseolina with five fungal and one bacterial antagonists are presented in Table 2 and depicted in Fig.5 and PLATE II. Results revealed that all the bioagents evaluated exhibited fungistatic / antifungal activity against $M$. phaseolina and significantly inhibited its growth over untreated control.

Amongs the bioagents/antagonists tested, $T$. viride was found most effective with significantly least mycelial growth $(18.00 \mathrm{~mm})$ and highest mycelial growth inhibition $(80.00 \%)$ of the test pathogen as compared to control. The second and third best antagonists were found $T$. harzianum and $T$. hamatum with second and third least mycelial growth of $20.66 \mathrm{~mm}$ and $34.00 \mathrm{~mm}$ and inhibition of 77.07 and 66.22 per cent, respectively. These were followed by $T$. koningii and $P$. fluorescens $(34.33$ and $38.33 \mathrm{~mm})$ and (61.85mm and $57.04 \%)$ of mycelium growth and its inhibition, respectively. $T$. virens was found comparatively less effective with maximum mycelial growth $(42.00 \mathrm{~mm})$ and minimum mycelial inhibition (53.33\%).

Results of the present study on antifungal activity of the $T$. viride, $T$. harzianum, $T$. hamatum $T$. koningii and T.virens one bacterial antagonists viz., $P$. fluorescens against $M$. phaseolina are in conformity with those reported earlier by several workers (Hazarika and Das, 1998; Jahagirdar et al., 2001; Kaur et al., 2008; Lokesha and Benagi, 2007; Pan and Bhagat, 2007; Das et al., 2008; Suyawanshi et al., 2008; Meena and Sangit, 2010; Kumari et al., 2012; Shrishail et al., 2012 and Amreen and Sanathkumar, 2013).

\section{References}

Anonymous (2013). Safflower. Annual Progress Report of DOR, 3:101-107.

Amar singh and T.P. Bhowmik (1979). Occurance of charcoal rot of safflower in India. Indian Phytopath., 32:626-627.

Amreen, T. and Sanathkumar, V. B. (2013). Sensitivity of Macrophomina phaseolina (Tassi) Goid., causing collar rot of maize against antagonists, plant extracts and animal products. Res. J. Agril. Sci. 4(3): 372-374.

Das, I. K., Indira, S., Annapurna, A., Prabhakar, B. and Seetharama, N. (2008). Biocontrol of charcoal rot in sorghum by Pseudomonas fluorescens associated with the rhizosphere. Crop Prot. 27:1407-1414.

Hazarika, D. K. and Das, K. K. (1998). Biological management of root rot of French bean (Phaseolus vulgaris L.), caused by Rhizoctonia solani. Pl. Dis. Res. 13 (2): 101-105.

Jahagirdar, S., Patil, M. S. and Indra, S. (2001). Biological control of charcoal rot of sorghum caused by $M$. phaseoina (Tassi) Goid. Agril. Sci. Digest. 21 (3): 153-156.

Kaur, S., Singh, N. and Sandhu, P. S. (2008). 
In vitro evaluation of Trichoderma viride and $T$. harzianum against $M$. phaseolina, causing charcoal root rot of sunflower. Pl. Dis. Res. 25 (1): 79.

Kore., S. S. and R. W. Deshmukh (1982). Charcoal rrot rot of safflower caused by Macrophomina phaseolina (Tassi) Goid Res. Bull. Marathwada Agril. Univerc., 6:43-45.

Kumari, R., Shekhawat, K. S., Gupta, R. and Khokhar, M. K. (2012). Integrated management against root-rot of Mungbean [Vigna radiata (L.) Wilczek], incited by Macrophomina phaseolina. J. Pl. Pathol. Microbiol.3:136.

Lambhate, S. S., Chaudhari, G. K., Mehetre, S. S. and Zanjare, S R. (2002). In vitro evaluation of chemicals against root rot of cotton caused by Macrophomina phaseolina. J. Mah. Agric. Univ. 27 (1): 99-100.

Lokesha, N. M. and Benagi, V. I. (2007). Biological management of pigeonpea Dry root rot caused by Macrophomina phaseolina. Karnataka J. Agric. Sci.20 (1): $54-56$.

Lukade, G. M. (1992). Effect of organic soil amendments on root rot incidence of safflower. Madras Agric. J., 79 (3): 179181.

Malathi S. and S. Doraisamy (2003). Compatibility of $T$. harzianum with fungicides against $M$. phaseolinapl. Dis. Res. 18 (2): 139-143.

Magar, S. V., Kadam, J. J., Rite, S. C., Thaware, D. S. and Potphode, P. D. (2011). Exploration of plant extracts and fungal antagonists against Macrophomina phaseolina (Tassi.) Goid., causing leaf spot in greengram. Int. J. Pl. Prot. 4 (1): 30-33.

Meena, S., Shrama, R. C., Lokendra, S. and Ram, D. (2006). Morphological and pathogenic variability of Macrophomina phaseolina (Tassi)
Goid. incitant of chorcol rot of maize in India. Indian Phytopath. 59 (3): 294298.

Meena, S. and Sangit, K. (2010). Potantialbiocontrol agents for the management of $M$. phaseolina incitant of charcoal rot in maize. Arch. Phytopathol. Pl. Prot. 43 (4):379-383.

Moradia, A. M. and Khandar, R. R. (2011). Losses of yield of groundnut due to dry root rot (M. phaseolina) and their management under in vivo conditions. Int. J. Agril. Sci. 7(2): 282-285.

Nene, Y. L. and P. N. Thapliyal (1993). Fungicides in Plant Disease Control. $3^{\text {rd }}$ Ed. Oxford IBH Publ. New Delhi. pp: 507.

Pan, S. and Bhagat, S. (2007). Antagonistic potential of Trichoderma and Gliocladium spp. from West Bengal. J. Mycol. Pl. Pathol. 31 (2): 235-239.

Shambharkar, D. A. and D. V. Indi (1987). Causal organism of safflower diseases and their importance. AICRP on Oilseeds (Safflower), Solapur, Maharashtra, India.pp: 181.

Shrivastava, S. N. and Tripathi, R. C. (1998). Management of sugarbeet seedling disease complex by combination of fungicides. Indian Phytopath. 51(1): 7577.

Shrishail, M., Vastrad, B.D., Biradar, S.S., Karbhantnal S.Y., Wali and Arun, S. (2012). In vitro evaluation of bioagents for the management of charcoal rot of sorghum In Souvenior of $3^{\text {rd }}$ Global Conference (ISMPP) on "Plant Pathology for Food Security", held at MPUAT, Udaipur, January 10-13, pp.140.

Singh, S. N.; Shrivastav, S. K. and M. N. Khare (1987). Effect of varying nitrogen doses and dates of sowing on the incidence of root rot (Rhizoctonia bataticola) and leaf spot (Alternaria carthami) diseases of safflower. J. 
Mycol. Pl. Pathol., 17(3): 351-352. Suryawanshi A. P. D. D. Gore, D. B. Gawade, A. K. Pawar and A. G. Wadje (2008). Efficiency of funcgicides against Macrophomina blight of mungbean. J. Pl. Dis. Sci. 3 (1): 40-42.

Tandel, D. B., Sabalpara, A.N. and Pandya,
J.R. (2010). Efficacy of fungicides and phytoextrats against green gram leaf blight caused by Macrophomina phaseolina. J. Pl. Dis. Sci. 5(1):48-50.

Vincent, J.M. (1927). Distortion of fungal hyphae in the presence of certain inhibitors, Nature: 159-180.

\section{How to cite this article:}

Gholve, V.M., P.N. Gawande and Ghuge, S.B. 2020. In vitro Bio-Efficacy of Fungicides and Bioagents against Dry Root Rot of Safflower. Int.J.Curr.Microbiol.App.Sci. 9(08): 3926-3938. doi: https://doi.org/10.20546/ijcmas.2020.908.452 